Лука Меденица

Белградский университет Филологический факультет

Кафедра славистики

medenicaluka@yahoo.com
УДК 811.161.1:37

https://doi.org/10.18485/slavistika.2020.24.2.21

стручни рад

примљено12.03.2020.

прихваћено за штампу 18.09.2020.

\title{
МЕТОДИЧЕСКИЕ РЕКОМЕНДАЦИИ НАЧИНАЮЩЕМУ ПРЕПОДАВАТЕЛЮ ПО РАБОТЕ НАД АУДИРОВАНИЕМ
}

В статье речь идёт об аудировании, поскольку оно всё чаще привлекает внимание методистов. Обучение восприятию речи на слух представляет собой один из самых важных аспектов обучения общению. Аудирование, пожалуй, является одним из самых сложных видов речевой деятельности с точки зрения обучения. В статье говорится о трудностях, с которыми сталкиваются начинающие преподаватели при работе с аудированием на уроках русского языка как второго иностранного в сербских школах. Автор рассматривает возможные пути преодоления выявленных проблем и даёт методические рекомендации, которые помогут начинающему преподавателю при обучении аудированию.

Ключевые слова: аудирование, методические рекомендации, начинающий преподаватель, русский язык как иностранный

The present report deals with listening. Listening is once again attracting the attention of second language acquisition researchers and teachers. Listening comprehension is an important part of learning language and effective communication. The listening skill is perhaps one of the most difficult and most challenging skills to teach. This paper presents the most common mistakes beginning teachers of Russian as a foreign language tend to make when they teach listening in Serbian schools. The author considers the ways of overcoming the identified problems and gives practical recommendations that will help the beginning teacher to improve teaching skills.

Keywords: listening comprehension, methodological recommendations, beginning teacher, $\mathrm{Ru}-$ ssian as a foreign language.

Ещё пятнадцать лет тому назад Кончаревич (Кончаревић 2004: 202) указала на важные статистические данные, согласно которым в течение одного дня человек в среднем тратит 45\% времени на слушание. Если учесть, что в современном мире основным источником информации для молодого поколения становятся Интернет и социальные сети, то не составит труда сделать вывод, что это подразумевает ещё большее количество аудио- и видеоматериалов. Проблема обучения восприятию русской речи на слух представляет собой важный аспект в обучении общению в искусственной языковой среде. С точки зрения обучения, аудирование, пожалуй, является одним из самых сложных видов речевой деятельности, особненно для начинающего преподавателя. К тому же, нельзя не согласиться с Дурбабой (Дурбаба 2011: 187), что, несмотря на важность аудирования в обучении и готовность уделять ему больше времени и внимания, аудирование не имеет даже равного положения с другими аспектами в процессе обучения, тем более лидирующего. Имея это в виду, в статье говорится о трудностях начинающего преподавателя в работе с аудированием на уроках русского языка как второго иностранного в сербских школах и путях преодоления вы- 
явленных проблем. Второй иностранный язык в сербских школах изучается с пятого класса, и доля русского языка по количеству школьников, изучающих его, составляет около $20 \%$ среди всех иностранных языков ${ }^{1}$.

Главной причиной, побудившей автора к написанию данной статьи, стали типичные ошибки, выявленные им в ходе показательных уроков, проводимых магистрантами в рамках экзамена по дисцисплине „Методичекая практика“ на Филологическом факультете в Белграде с 2014 по 2020 год. В ходе исследования магистранты провели 107 уроков, состоявшихся в белградских школах, с которыми на момент проведения урока был подписан договор о сотрудничестве. Это школы: Первая белградская гимназия, Восьмая белгдрадская гимназия, восьмилетняя школа имени Двадцатого октября, восьмилетняя школа имени Ивана Горана Ковачича, восьмилетняя школа имени Петра Кочича. В исследовании был применён метод наблюдения, причём исследователь не участвовал в процессе обучения, что дало ему возможность быть более объективным при ведении протокола. В протоколе наблюдения фиксируются необходимые для анализа урока сведения. Для данной статьи важно отметить, что в каждом протоколе есть информация об использовании аудиовизуальных средств, времени использования данных средств на конкретном уроке, а также поведении учителя и учащихся. В поурочном плане к каждому уроку есть и описание этой деятельности, и замечания наблюдателя. Немаловажным является тот факт, что часть магистрантов к моменту проведения экзаменационного урока уже имела определенный опыт работы (до двух лет) в сербских школах или на языковых курсах, а также опыт работы репетитором.

Как отмечает Акишина (Акишина и др. 2014: 82), аудирование - устный репродуктивный вид речевой деятельности. Аудирование - это не просто пассивное слушание, потому что оно подразумевает получение информации (от собеседника или из другого источника). Просмотр мультфильмов, фильмов и прослушивание музыки на уроке без определённой цели могут положительно повлиять на мотивацию, формирование социокультурной компетенции и даже на увеличение словарного запаса, но это не совсем аудирование, рассматриваемое в статье, так как такой вид деятельности на уроке не обязательно подразумевает привлечение необходимых для аудирования умений. Такую деятельность можно назвать аудированием «для удовольствия», чем ученикам, несомненно, стоит как можно больше заниматься вне класса. Естественно, роль преподавателя мотивировать учеников проделывать эту работу в свободное время. В классе же более разумным и полезным является целенаправленное использование аудио- и видеоматериалов, а это требует огромной подготовки со стороны преподавателя. К тому же, начинающему преподавателю иногда необходимо писать и задания к этим материалам, в соответсвии с конкретным уровнем владения русским языком. Как отмечают Раичевич, Дурбаба и Кончаревич (Раичевић 2007; Дурбаба 2011; Кончаревић 2004), это не обязательно должны быть задания на проверку понимания прослушанного, но это могут быть и разные творческие задания. На первое время начинающим преподавателям советую подби-

${ }^{1}$ Подробнее о положении русского языка в школах Сербии пишут сербские методисты (Гинић 2018; Марич 2015; Марковић 2014, Ђурић 2016) 
рать аудио- и видеоматериалы из пособий и учебников по РКИ² и для практики видоизменять задания к этим материалам, а время от времени самостоятельно писать задания и находить аутентичные аудио- и видеоматериалы, чтобы сравнивать реакции и результаты. Стоит подчеркнуть, что начинающему преподавателю также необходимо заранее прослушать все материалы, которые он собирается использовать на уроке, с целью предвидеть потенциальные „опасности“ и проблемы и вовремя отреагировать. Об аудировании следует очень серьёзно думать во время подготовки к уроку.

Начинающий преподаватель может подумать, что достаточно того, что он говорит на уроке по-русски. Однако ученики должны слышать и чужую речь. В сербских школах один и тот же преподаватель ведёт уроки на протяжении четырёх лет (с пятого по восьмой классы восьмилетней или с первого по четвёртый классы средней школы). Даже если преподаватель русскоговорящий, то всё равно ученикам необходимо слышать речь и другого человека, не только преподавателя. По разным причинам: аутентичность, большее количество голосов в диалоге/полилоге, что является более естественным, другой темп, другая интонация и тому подобное. Также следует отметить не только особенности говорящих, но и слушающих. Особенно интересной для начинающего преподавателя в продолжение данного списка является такая особенность, как дисциплина учеников на уроке, хотя она не имеет прямого отношения к аудированию. На 90\% уроков, проведённых магистрантами в рамках „Методической практики“, дисциплина во время чтения текста учителем была на более низком уровне, по сравнению с прослушиванием аудиоматериала. Причина в том, что преподаватель мог следить за учениками: что они делают, куда смотрят, как себя ведут, а также делать невербальные замечания, что с трудом даётся начинающему преподавателю, если ему приходится читать текст. Маловероятно, что у поколения начинающих преподавателей низкий уровень компьютерной грамотности. Но даже в таких случаях, необходимо обращаться к ученикам, которые, я уверен, достаточно хорошо умеют пользоваться современными технологиями, и таким образом повышать уровень своей компьютерной грамотности. Чуть больше $51 \%$ участвовавших в исследовании магистрантов, несмотря на наличие аудиозаписи в рамках учебно-методического комплекса, не использовали аудиовизуальные средства обучения на уроке. Нужно подчеркнуть, что сначала, в 20142015 годах, около 80\% магистрантов совершало эту ошибку, но затем процент начал уменьшаться. В последующие три года он составлял 50\%, а в последние два года всего 20\%. Резкий спад можно объяснить не только увеличением продолжительности педагогической практики и изменением соотношения объема пассивной и активной практики магистрантов в сторону уменьшения первого (Меденица 2020), но и увеличением количества методических дисциплин в рамках Белградского университета (Гинич и др. 2020), что, несомненно, повлияло на повышение уровня профессиональной подготовки будущих педагогов-русистов. Отрицательным примером может служить урок, на котором магистрант решил сам прочитать полилог из учебника, хотя в тексте, кроме слов

\footnotetext{
${ }^{2}$ Очень ценным для сербских преподавателей стал и опубликованный государственным институтом оценки качества образования сборник заданий, написанный по образовательным стандартам Сербии (Дурбаба и др. 2017).
} 
автора, ещё четыре героя: Лена, Ира, Макс и Витя. Кроме того, в книге для преподавателя ясно указано, что в данном задании сначала следует прослушать аудиозапись (Меденица 2015: 42). Особенно запоминающимся был урок, на котором магистрант попросил учеников открыть учебник и следить за текстом, пока он его будет читать. Затем магистрант так сосредоточенно читал текст, не поднимая глаз от учебника, что не заметил, как некоторые ученики подняли руки, чтобы сообщить своему новому учителю о том, что в их учебнике нет такого текста. С другой стороны, есть и большое количество положительных примеров, когда магистранты использовали не только аудиозаписи, входящие в состав учебно-методического комплекса, но и дополнительные аудиовизуальные средства: художественные фильмы, мультфильмы, песни и прочее. В пятом классе магистрант показал короткий фрагмент мультфильма «Маша и Медведь» при обработке темы «Новый год», попросив учеников назвать все услышанные ими слова, которые относятся к этому празднику. При обработке темы «Знакомство» ученикам первого класса гимназии было предложено послушать аудиозапись, в которой несколько лиц знакомятся, а затем ученики на доске составили ментальную карту с словами из записи, выделив два направления: знакомство при посреднике и знакомство без посредника. Ментальную карту дополняли на протяжении всего урока.

Иногда в учебнике нет достаточного количества вопросов, которые относятся к аудиоматериалу, а преподавателю хочется больше времени уделить аудированию и текстовым или послетекстовым заданиям. Начинающему преподавателю стоит обратить внимание на одну типичную ошибку, иногда допускаемую даже опытными учителями при составлении самих вопросов. Рассмотрим приведённые ниже вопросы.

1. Куда ходил Серёжа в субботу?
А) В кино.
Б) На футбол.
В) В театр.
Г) В гости.

2. С кем Серёжа ходил в кино?
А) С Дашей.
Б) С Машей.
В) С Пашей.
Г) С Володей.

3. Почему Маше не понравился фильм? 
Когда ученик подходит ко второму вопросу и читает его, включается лампочка. Отвечая на первый вопрос, он уже целенаправленно читает следующий в надежде, что там скрывается ответ. Так как вопросы преподаватель зачастую даёт одновременно, то необходимо всегда проверять, не прячется ли в последующем вопросе ответ на предыдущий. Чтобы избежать логических ошибок при составлении вопросов к заданию по аудированию, советую читать их в обратном порядке, начиная с последнего.

Начинающий преподаватель, при выполнении задания по аудированию, может встретиться и с такой проблемой: в учебнике есть текст записи. Текст может находиться непосредственно в рамках данной темы/урока или в конце учебника. Несмотря на то, что он есть в учебнике, это не означает, что текст нельзя использовать в работе над аудированием. Необходимо всё продумать более тщательно. Во-первых, необходимо выполнять задания по аудированию без параллельного просмотра текста (за исключением определённых текстовых заданий), то есть параллельного чтения. Преподавателю нужно заранее продумать, когда ученики должны закрыть учебник или только текст листом бумаги. Кроме того, не стоит раздавать дополнительные материалы слишком рано (если там текст) и рассчитывать на то, что ученики будут внимательно слушать, несмотря на то, что перед ними текст. В подобных ситуациях ученик чаще всего слышит что-то, но уже не обращает на это внимание, потому что он старается сосредоточиться на чтении. В данном случае это плохо, потому что преподаватель должен стремиться привлечь конкретные умения и способности ${ }^{3}$. Запоминающимся отрицательным примером может служить урок, на котором магистрант попросил учеников слушать текст и читать его про себя, а затем задавал вопросы по тексту. К сожалению, ученики ответы искали в самом тексте, а значит, они не привлекли необходимые для аудирования умения и способности, хотя в поурочном плане задание было направлено именно на аудирование. Положительным примером может служить постепенно усложняющееся задание, когда магистрант после первого прослушивания попросил учеников шестого класса ответить на один простой вопрос (О каком городе идёт речь?), после второго - на несколько более сложных (Как ещё называют этот город? Что можно посмотреть в июне в Петербурге?), после третьего - на ещё более сложные (Что вчера делал Юра? Что он делал в Петербурге? Давайте ещё раз скажем, как ещё называют Петербург? А почему его так называют? В каком месяце Юра посетил Петербург? Когда в Петербурге Белые ночи? Что говорит Юра, что можно делать тогда ночью?), а только потом, когда ответов уже не было или их было очень мало, ученики открыли текст и работали с ним (Амштајн-Баман и др. 2015: 25):

«Вчера мы долго гуляли по улицам Петербурга. Экскурсия мне очень понравилась. Какие красивые мосты и каналы! Теперь я понимаю, почему говорят, что Петербург - это «Северная Венеция». А ещё жаль, что мы не были здесь в июне. В этом месяце в городе Белые ночи. На улицах ночью совсем светло! Можно даже читать без лампы».

\footnotetext{
3 Подробнее об умениях, небходимых для чтения и аудирования пишет Акишина (Акишина 2014).
} 
Популярным источником аутентичных материалов для чуть более половины магистрантов, проводивших уроки в пятом и шестом классах, являлись сказки и мультфильмы. Тут нужно быть очень внимательным при составлении вопросов. Рассмотрим приведённые ниже вопросы. Они могут быть открытого или закрытого типа, хотя, как уже было отмечено в анализе результатов сербских школьников при поступлении в гимназии с билингвальным обучением (Меденица и др. 2018), вопросам открытого типа следует уделять больше внимания в обучении аудированию.

\section{1. Сколько было братьев поросят?}

2. Какой дом построил первый поросёнок?

3. Какой дом построил второй поросёнок?

4. Какой дом построил третий поросёнок?

Каждый ребёнок, которому родители читали в детстве эту сказку на родном языке, без затруднений ответит на приведённые выше вопросы. Я, естественно, немного утрирую, но считаю, что если достаточно упростить, то легче запомнить данную рекомендацию. Если преподаватель намеревается дать задание по аудированию, используя в качестве аудиозаписи знакомую детям историю или сказку, то особое внимание необходимо обратить на содержание вопросов. В противном случае, некоторые ученики смогут ответить на вопросы без прослушивания записи, а это уже не аудирование.

Несомненно, компьютерные технологии могут обеспечить интересные учебные ситуации, но, как подчёркивает Пешикан (Пешикан 2016), это не происходит автоматически, когда оборудование приносят в класс. Учителя, а также ученики, должны научиться пользоваться его преимуществами. В данной статье представлены рекомендации, которые помогут начинающему преподавателю правильно пользоваться этими преимуществами, а именно: начинающему преподавателю стоит различать аудирование «для удовольствия» и целенаправленное аудирование, на первое время подбирать материалы из учебников и по возможности видоизменять задания, находить аутентичные материалы при самостоятельном написании задания, заранее прослушивать все используемые на уроке материалы, использовать аудиовизуальные средства обучения при каждой возможности, а не ,заменять“ аутентичную речь своей, заранее продумать, когда нужно раздать дополнительные материалы и нужно ли ученикам смотреть в текст, всё с целью привлечь небоходимые для аудирования, а не чтения, умения, обращать внимание на логические ошибки при составлении вопросов, чтобы в последующих вопросах не скрывались ответы на предыдущие, особое внимание обращать на вопросы к материалам, содержание которых ученикам может быть заранее известно. Естественно, данные в статье рекомендации не охватывают всех трудностей, возникающих у начинающего преподавателя. Удалось обсудить лишь некоторые аспекты этой проблемы. В будущем предстоит рассмотреть и вопросы, которые относятся к длине аудиозаписи и количестве прослушиваний, следует обсудить, нужно ли давать вопросы до прослушивания текста или после, какие умения мы больше в таком случае привлекаем, нужно 
ли учитывать орфографические и грамматические ошибки в ответах на вопросы открытого типа, какие типы аудирования существуют, а также многое другое. Однако, рассмотрев предложенные пути преодоления выявленных в статье проблем, начинающий преподаватель имеет возможность улучшить свои преподавательские навыки. Искренне надеюсь, что методические рекомендации, представленные в статье, смогут побудить преподавателя больше думать об этой теме, помогут ему в обучении аудированию и обеспечат фундамент для дальнейшего правильного использования материалов по аудированию на уроке.

\section{Использованная литература}

Акишина, Алла А., Ольга Е. Каган. Учимся учить: для перподавателя русского языка как иностранного, девятое издание. Москва: Русский язык. Курсы, 2014.

[Akishina, Alla A., Ol'ga E. Kagan. Uchimsiā uchit': dliā perpodavateliā russkogo iâzyka kak inostrannogo, deviâtoe izdanie. Moskva: Russkiū iāzyk. Kursy, 2014]

Гинић, Јелена. «Настава руског језика у основној школи: актуелно стање и перспектива». [У:] Ј. Вучо, Ј. Филиповић (ур.) Језици образовања. Београд: Филолошки факултет Универзитета у Београду, 2018, 109-120.

[Ginić, Jelena. «Nastava ruskog jezika u osnovnoj školi: aktuelno stanje i perspektiva». [U:] J. Vučo, J. Filipović (ur.) Jezici obrazovanja. Beograd: Filološki fakultet Univerziteta u Beogradu, 2018, 109-120]

Гинич, Елена, Наташа Айджанович, Лука Меденица. «Современное положение русского языка в высших учебных заведениях Сербии». [У:] Љ. Бајић, Ј. Гинић, Н. Станковић Шошо (ур.) Положај словенских језика, књижевности и култура на универзитетима у свету. Округли сто Комисије за наставу словенских језика и књижевности Међународног комитета слависта. Београд: Филолошки факултет Универзитета у Београду, 2020, 18-47.

[Ginich, Elena, Natasha Aĭdzhanovich, Luka Medenitsa. «Sovremennoe polozhenie russkogo iāzyka v vysshikh uchebnykh zavedeniiakh Serbii». [U:] Lj. Bajić, J. Ginić, N. Stanković Šošo (ur.) Položaj slovenskih jezika, književnosti i kultura na univerzitetima u svetu. Okrugli sto Komisije za nastavu slovenskih jezika i književnosti Međunarodnog komiteta slavista. Beograd: Filološki fakultet Univerziteta u Beogradu, 2020, 18-47]

Дурбаба, Оливера. Теорија и пракса учења и наставе страних језика. Београд: Завод за уџбенике, 2011.

[Durbaba, Olivera. Teorija i praksa učenja i nastave stranih jezika. Beograd: Zavod za udžbenike, 2011]

Дурбаба, Оливера, Љиљана Ђурић, Ана Јовановић, Катарина Завишин, Јелена Гинић, Лука Меденица, Александра Секулић, Јелена Рашевић. Општи стандарди постигнућа за крај основног образовања за страни језик. Београд: Завод за вредновање квалитета образовања и васпитања, 2017.

[Durbaba, Olivera, Ljiljana Đurić, Ana Jovanović, Katarina Zavišin, Jelena Ginić, Luka Medenica, Aleksandra Sekulić, Jelena Rašević. Opšti standardi postignuća za kraj osnovnog obrazovanja za strani jezik. Beograd: Zavod za vrednovanje kvaliteta obrazovanja i vaspitanja, 2017]

Ђурић, Љиљана. Страни језици у образовној политици Србије. Београд: Филолошки факултет Универзитета у Београду, 2016. 
[Đurić, Ljiljana. Strani jezici u obrazovnoj politici Srbije. Beograd: Filološki fakultet Univerziteta u Beogradu, 2016]

Кончаревић, Ксенија. Савремена настава руског језика (садржаји, организација, облици). Београд: Славистичко друштво Србије, 2004.

[Končarević, Ksenija. Savremena nastava ruskog jezika (sadržaji, organizacija, oblici). Beograd: Slavističko društvo Srbije, 2004]

Марич, Биляна. «Состояние и перспективы изучения русского языка в инославянской среде». Этнодиалоги 1, 2015: 26-34.

[Marich, Biliâna. «Sostoiânie i perspektivy izucheniiârusskogo iâzyka v inoslaviânskoĭ srede». Ėtnodialogi 1, 2015: 26-34]

Маркович, Деян. «Преподавание русского языка в Сербии, актуальные проблемы в сокращении часов и возможные пути их решения». Наука и савремени универзитет 4, 2014: 148-153.

[Markovich, Deiân. «Prepodavanie russkogo iâzyka v Serbii, aktual'nye problemy v sokrashchenii chasov i vozmozhnye puti ikh resheniiâ». Nauka i savremeni univerzitet 4, 2014: 148-153]

Меденица, Лука. «Актуальное состояние педагогической практики для русистов на филологическом факультете Белградского университета». Русистика без граници 3, 2020, 77-84.

[Medenitşa, Luka. «Aktual'noe sostoiānie pedagogicheskoĭ praktiki dliâ rusistov na filologicheskom fakul'tete Belgradskogo universiteta». Rusistika bez granitsi 3, 2020, 77-84]

Меденица, Лука. Конечно! 2: руски језик за шести разред основне школе: приручник за наставнике. Београд: Klett, 2015.

[Medenica, Luka. Konečno! 2: ruski jezik za šesti razred osnovne škole: priručnik za nastavnike. Beograd: Klett, 2015]

Меденица, Лука, Јелена Гинић. «Постигнућа ученика на пријемном испиту за упис у руско-српска билингвална одељења». Примењена лингвистика 19, 2018, 23 30 .

[Medenica, Luka, Jelena Ginić. «Postignuća učenika na prijemnom ispitu za upis u rusko-srpska bilingvalna odeljenja». Primenjena lingvistika 19, 2018, 23-30]

Пешикан, Ана. «Најчешће заблуде о информационо-комуникативним технологијама у образовању». Настава и васпитање 1, 2016: 31-46.

[Pešikan, Ana. «Najčešće zablude o informaciono-komunikativnim tehnologijama u obrazovanju». Nastava i vaspitanje 1, 2016: 31-46]

Раичевић, Вучина. Општа методика наставе словенских језика у инословенској средини. Београд: Завод за уџбенике, 2007.

[Raičević, Vučina. Opšta metodika nastave slovenskih jezika u inoslovenskoj sredini. Beograd: Zavod za udžbenike, 2007]

\section{Источники}

Амштајн-Баман, Кристине, Улф Боргварт, Моника Брош, Данута Генч, Петер Јакубов, Ролф Лашет, Наталија Осипова-Јос, Гизела Рајхерт-Боровски, Евелин Валах, Драгана Керкез, Јелена Гинић. Конечно! 2: руски језик за шести разред основне школе: уџбеник за другу годину учења. Београд: Klett, 2015. 
[Amštajn-Baman, Kristine, Ulf Borgvart, Monika Broš, Danuta Genč, Peter Jakubov, Rolf Lašet, Natalija Osipova-Jos, Gizela Rajhert-Borovski, Evelin Valah, Dragana Kerkez, Jelena Ginić. Konečno! 2: ruski jezik za šesti razred osnovne škole: udžbenik za drugu godinu učenja. Beograd: Klett, 2015]

\title{
Лука Меденица
}

\section{МЕТОДИЧКЕ ПРЕПОРУКЕ НАСТАВНИКУ-ПОЧЕТНИКУ У НАСТАВИ РАЗУМЕВАҢА ГОВОРА}

\begin{abstract}
Резиме
Рад се бави разумевањем говора. Наведено питање све више привлачи пажњу лингводидактичара. Чињеница је да су савремени медији у све већој мери у облику аудио и видео записа, стога је положај разумевања говора у настави руског језика од изузетне важности, а нарочито уколико узмемо у обзир и чињеницу да стицање комуникативне компетенције представља осовни циљ учења руског језика. Разумевање говора свакако представља један од најкомплекснијих и најизазовнијих видова говорне делатности и када је настава у питању. Аутор рада указује на најчешће неправилности које се могу јавити код наставника-почетника у настави разумевања говора и начине превазилажења идентификованих проблема кроз практичне методичке препоруке.
\end{abstract}

Кључне речи: разумевање говора, методичке препоруке, наставник-почетник, руски језик као други страни. 